\title{
A LIBERDADE NA ORDEM ESCRAVOCRATA: INTERPRETAÇÕES SOBRE O CONTO PAI CONTRA MÃE, DE MACHADO DE ASSIS
}

\author{
FREEDOM UNDER SLAVERY: INTERPRETATIONS OVER MACHADO DE ASSIS' FATHER
}

AGAINST MOTHER

Paulo Henrique Rodrigues Pereira*

\begin{abstract}
Resumo:
As instituições jurídicas da escravidão deixaram um legado profundo na sociedade brasileira. Ao mesmo tempo, a literatura tem cada vez mais fornecido o subsídio para uma análise aprofundada da prática jurídica na sociedade, enxergando o direito como linguagem. O presente artigo busca, a partir dessas premissas, traçar uma análise do conto Pai contra Mãe de Machado de Assis, um raro exemplo da abordagem do escritor sobre o tema da escravidão, extraindo dela a percepção da sociedade da condição de liberto e de escravizado na ordem escravocrata, explorando os aspectos jurídicos, como a realidade pré-Lei do Ventre Livre, por meio dos diálogos das personagens. Assim, apresentando um panorama do conto, espera-se fornecer ao leitor um retrato da percepção e prática de institutos jurídicos quando sob a escravidão no Brasil do século XIX.

Palavras-chave: Direito e Literatura. Machado de Assis. História do Direito. Teoria do Direito Brasileiro. Direito da Escravidão.
\end{abstract}

\begin{abstract}
:
The legal institutions of slavery have left a deep legacy in Brazilian society. At the same time, literature has increasingly provided the support for an in-depth analysis of legal practice in society, understanding law as a language. This paper seeks, based on these premises, to trace an analysis of Machado de Assis' short story Pai contra Mãe, a rare example of writer's approach to the slavery subject, extracting from it society's perception of the condition of released and enslaved individuals under slave rule, exploring legal aspects, such as the pre-Free Womb Law reality, through the dialogues of the characters. Thus, by presenting an overview of the short story, it is expected to provide the reader with a portrait of the perception and practice of legal institutes when under slavery in Brazil in the 19th century.

Keywords: Law and Literature. Machado de Assis. Legal History. Brazilian Theory of Law. Slavery Law.
\end{abstract}

* Doutorando pela Faculdade de Direito da USP; Pesquisador Visitante na Universidade de Harvard em 2020 (FAS-ALARI). 
1. Introdução

Publicado em 1906, Pai contra Mãe é talvez o texto em que Machado de Assis mais diretamente tenha tratado do tema da escravidão. ${ }^{1}$ Considerando a importância de sua obra, e a existência de um já antigo debate sobre a sua eventual negligência acerca do mais central dos temas sociais do seu tempo (PUGLIESI, 2018), o conto publicado no "Relíquias da Casa Velha" acabou por se tornar central na discussão sobre escravidão e literatura no Brasil. Esse breve artigo pretende analisá-lo, buscando nos seus elementos textuais caminhos para uma breve apresentação do mundo dos homens livres na ordem escravocrata do Brasil do século XIX. ${ }^{2}$

O texto conta a história de Cândido Neves, homem livre, que dedica a vida a procurar escravizados fugidos. Buscando anúncios em jornais, o protagonista do conto de Machado procura restituí-los aos seus donos em troca de recompensas pecuniárias. A história ganha dramaticidade quando Clara, sua esposa, se descobre grávida, e a expectativa do aparecimento de uma criança cria tensões na precariedade da condição econômica familiar. Prestes a ter que abdicar do convívio e criação do filho, o entregando à adoção, Cândido se lança ao desenfreado processo de caçar uma escravizada, cuja alta recompensa poderia lhe permitir continuar com a criança. O desfecho cruel do conto se dá com a revelação de que Arminda - a escravizada que havia fugido - também estava grávida, de modo que a oposição final da história se dá entre o choque dos direitos de criar dignamente um filho, entre os interesses do pai e da mãe.

$\mathrm{Na}$ abordagem que se pretende fazer neste breve texto, se defenderá que o discurso de Machado se orienta pela ideia da existência de uma dependência estrutural que articula as misérias de Cândido e Arminda. A disputa entre o direito à paternidade/ maternidade de ambos se representa como a demonstração particular de um sistema que integra a sorte dos horizontes dos atores subordinados, a partir da construção de instituições senhoriais. Como se buscará demonstrar, a ordem escravocrata constrange as forças sociais constituídas, e drena os potenciais sociais de modo a limitar as possibilidades de desenvolvimento dos não possuidores. Para isso, esse artigo reconstituirá brevemente as condições estruturais da vida dos homens livres no século XIX brasileiro, buscando demonstrar como não é possível pensá-los fora das condições sociais da ordem escravocrata.

1 Como bem demonstrou Sidney Chalhoub, a escravidão foi tema presente de toda a obra de Machado de Assis. Ele tratou mais diretamente do assunto em, pelo menos, três contos além de Pai contra Mãe: $O$ caso da Vara, O Espelho e Mariana. Vide Chalhoub (2003).

2 Utilizo aqui um termo praticamente idêntico ao da importante obra de Maria Sylvia de Carvalho Franco. Vide Franco (1997). 
Para isso, se enfrentará o seguinte programa: (i) em primeiro lugar, se fará uma reconstituição dos elementos presentes no conto de Machado que são importantes para a análise do tema escolhido. Essa etapa acabará por ser mais longa, porque mobilizará muitos dos elementos a serem usados na segunda parte; em seguida (ii) se apropriará da literatura especializada, para levantar o quadro de subordinação dos homens livres no sistema econômico periférico e dependente do Império do Brasil.

$\mathrm{Na}$ primeira parte, em que se analisará o conto de forma mais cuidadosa, serão analisados três aspectos centrais. Em primeiro lugar, se buscará compreender o arco temporal entre o momento da publicação do conto e a história nele narrada. Nesse momento, vale se perguntar qual é o sentido contextual do aparecimento desse texto na última coletânea de história de Machado; depois, se analisará as principais características do narrador do texto. Se quer entender os elementos ideológicos que conformam a moldura narrativa da história, e que revelam o posicionamento do narrador. Na leitura que se fará aqui, a conjuntura da formação da narração auxilia no processo de entendimento das críticas tecidas por Machado às instituições de seu tempo. No fim desse primeiro esforço, serão levantados no texto os elementos da vida de Cândido e Clara que podem ser úteis para situá-los socialmente. Esse movimento será a ponte para a segunda parte do trabalho, na qual serão organizadas as reflexões sobre o mundo das pessoas livres na ordem escravocrata do Brasil imperial.

Com os elementos selecionados a serem explorados a partir do conto, se fará um levantamento das condições estruturais de vida dos homens livres na ordem escravocrata. A hipótese por trás dessa parte do artigo é a de que há um regime de limitação dos horizontes e das expectativas de vida dos homens e das mulheres livres que decorre exclusivamente da presença de um escravismo total. Serão analisados três aspectos como formadores dessa limitação: o direito, o estado da formação econômica daquela sociedade, bem como as construções ideológicas do papel dos não brancos em um regime escravocrata tão violento como o brasileiro. Os dois últimos aspectos serão tratados conjuntamente.

\section{Pai contra Mãe \\ Arco temporal da história: escrita e enredo}

Machado de Assis publicou Pai contra Mãe no seu Relíquias da Casa Velha, em 1906, dois anos antes de morrer. O livro, última coletânea de textos do escritor, trouxe histórias que já haviam sido publicadas na imprensa antes, juntamente com contos inéditos, como era o caso de Pai contra Mãe. Machado confere um tom histórico a esse conjunto de história, assumindo um caráter testemunhal de um mundo que parece não mais existir. Diz ele na advertência que abre a publicação que "uma casa tem muita vez 
as suas reliquias, lembranças de um dia ou de outro, da tristeza que passou, da felicidade que se perdeu. Supõe que o dono pense em as arejar e expor para teu e meu desenfado". Nem todas seriam interessantes, segundo ele, mas olhadas com cuidado, seria possível extrair algumas dignas de observação (ASSIS, 1994). A primeira relíquia da sua casa velha - metáfora da sua vida - foi justamente a escravidão retratada na violenta narrativa analisada.

Na obra ficcional de Machado, não foram muitos os textos explicitamente vocacionados ao tema da escravidão, como já mencionado acima. Para alguns, essa ausência foi tão sentida (PUGLIESI, 2018; DUARTE, 2007), que muito já se discutiu sobre a sua posição na literatura negra nacional. ${ }^{3}$ Por que, em momento do pós-abolição, o escritor resolvera tratar desse tema? Por que essa relíquia mereceria "sair cá fora", já no Brasil republicano? (ASSIS, 1994) Evidente que não é possível responder essa questão, mas algumas reflexões parecem ser pertinentes. Em primeiro lugar, vale dizer que o livro de 1906 está situado exatos dezoito anos depois da Lei Áurea. ${ }^{4}$ Comemorava-se a maioridade ${ }^{5}$ da liberdade dos escravizados, e talvez fosse momento de balanços.

O balanço de Machado parece cético (SCHNEIDER, 2018, p. 482). No seu último romance, publicado dois anos depois de Pai contra Mãe, o personagem principal dá um testemunho sobre a abolição. Embora não se possa fazer qualquer relação entre o Conselheiro Aires - personagem principal do romance - e Machado, é impossível não se atentar à sua descrição. A abolição vai frequentando as páginas do seu diário - o romance é escrito em forma de diário -, num crescendo do seu amadurecimento político, das conversas dos salões, das páginas dos jornais. No dia 13 de maio, escreve o Conselheiro: "enfim, lei. [...] Ainda bem que acabamos com isto. Era tempo. Embora queimemos todas as leis, decretos e avisos, não poderemos acabar com os atos particulares, escrituras e inventários, nem apagar a instituição da História, ou até da Poesia" (ASSIS, [1908?], p. 21).

O sentido imediato do trecho final da posição de Aires é de que não é possível esquecer a escravidão, apagar essa vergonhosa página da história nacional. Ficaria viva, como ficou, nos indícios da vida documentada da sociedade brasileira. Vale mencionar, entretanto, que a paisagem do romance é ilustrada por libertos que se mantinham como

\footnotetext{
3 Machado passou por um importante processo de embranquecimento ainda em vida. Fernando Rocha menciona simbolicamente que há alguns anos, uma propaganda comemorativa da Caixa Econômica Federal, por exemplo, utilizou um ator branco para representá-lo. Vide Rocha (2016).

4 A Lei Áurea, que aboliu a escravidão no Brasil, foi promulgada em 13 de maio de 1888.

5 Deve-se mencionar que a figura da maioridade utilizada aqui não é completamente apropriada. O Brasil ainda não tinha um Código Civil em 1906, e a doutrina entendia que a maioridade era de 21 anos. Vide Simão (2013).

Na Constituição de 1824, entretanto, foi o tempo de dezoito anos escolhido para o atingimento da maioridade do Imperador, por meio do Ato Adicional de 1834.
} 
antes, trabalhando com a mesma enxada "por amor à Sinhá" (ASSIS, [1908?], p. 93), ou outros que, embora livres, viviam com a mesma "afeição dos escravos". Assim, habilitase uma outra interpretação, a de que Aires faria uma consideração sobre a continuidade institucional de elementos constitutivos da escravidão (FRAGELLI, 2007).

A segunda interpretação fica interessante quando posta em frente à primeira oração de Pai contra Mãe. Diz o conto que "A ESCRAVIDÃO levou consigo ofícios e aparelhos, como terá sucedido a outras instituições sociais" (ASSIS, [1906?], p. 1). É interessante notar que os dois verbos colocados na primeira frase estão conjugados em diferentes tempos. Ao falar dos ofícios e aparelhos, Machado se utiliza da palavra levou, pretérito perfeito, indicando uma ação que se encerrou completamente no passado. Entretanto, ao tratar das instituições sociais, o autor utiliza terá. Conjugação mais incomum do verbo ter - futuro do presente do indicativo - dá um sentido condicional à ação, tratando de um fato que deve estar terminado antes um outro fato futuro (RIBEIRO, 1883, p. 200-201). Também aqui, existem duas possíveis interpretações. Machado pode estar comparando a escravidão a outras instituições sociais que poderiam acabar, ou pode estar sugerindo que embora os ofícios e aparelhos tenham sido extintos, não é possível se ter certeza sobre a extinção de instituições sociais ligadas à escravidão (MORAES, 2009, p. 10).

Em alguma medida, os marcos temporais da publicação do conto conduzem à compreensão de que Machado pode estar interessado em refletir sobre o estado do tema da escravidão, no momento de sua maioridade. Esse seria um tema superado? Quais as permanências sociais, culturais e conceituais da sua presença na sociedade brasileira?

Ao contar a história, o narrador transporta o leitor por meio século. O conto tem três momentos bem definidos: um primeiro, argumentativo, em que o narrador faz considerações genéricas sobre a escravidão, como se se tratasse de uma instituição muito antiga e longínqua. Como se verá a seguir, essa técnica é central para a compreensão da posição do narrador. Um segundo movimento, dessa vez narrativo, no qual se apresenta a história de Cândido e Clara. E por fim, o desfecho trágico que resolve o conflito apresentado por Machado como o aparecimento de uma nova personagem, Arminda.

Não existem indícios exatos sobre o momento histórico do desenrolar dos fatos narrados entre Cândido, Clara e Arminda. Entretanto, ao fazer o seu inventário do escravismo, o narrador situa a história há meio século, colocando o leitor nos anos de 1850. A década não é aleatória: esses foram anos centrais para o escravismo brasileiro. Em 1850, o Brasil proibiu definitivamente o tráfico negreiro, dando desfecho a uma história de contínuos descumprimentos das classes senhoriais às proibições de importação de novos escravizados. O crescimento da demanda global pelas commodities brasileiras - açúcar, tabaco, algodão, e principalmente café - deu força ao escravismo, que pôde descumprir dois tratados internacionais - um assinado ainda por Portugal na época colonial, e outro na 
regência - e uma lei que, em 1831, proibia o comércio, concedia a liberdade aos traficados e criminalizava a conduta dos contrabandistas (PARRON, 2011). Nos anos de 1850, portanto, uma parcela importante dos escravizados brasileiros era ilegal, justamente por terem sido traficados após essas proibições (MAMIGONIAN, 2017).

Paradoxalmente, a interrupção de entrada de novos escravizados no Brasil ocorreu justamente no momento de explosão das exportações de café para os grandes centros industriais do atlântico norte. A conjunção dos dois fatores aumentou a procura por mão de obra cativa, gerou aumento no preço do escravizado, criou movimentos de atração para as zonas mais competitivas - tráfico interprovincial -, e deu força às ilegalidades a serviço da escravidão (CONRAD, 1978). Juntaram-se aos diversos africanos livres, brasileiros afrodescendentes também reduzidos ilegalmente à escravidão (CHALHOUB, 2012). A antiga abundância de escravizados - marca da formação nacional - dá lugar a um novo ambiente onde escravo é artigo raro. É nesse contexto que os lucros de Cândido passam a escassear, pois novos concorrentes se apresentam à tarefa de procurar escravos fugidos (ASSIS, [1906?], p. 5).

Voltar a um dos momentos mais críticos do escravismo brasileiro poderia justamente auxiliar na compreensão de alguns lances centrais do seu legado estrutural.

\section{A posição do narrador}

Como mencionado acima, existem duas composições muito diferentes do trabalho empenhado pelo narrador da história. Para apresentar o enredo e os personagens do conto, o narrador realiza um levantamento dos aparelhos e dos ofícios que se foram com a escravidão. Em uma primeira leitura, os dois primeiros movimentos do texto podem parecer desconectados, sem aparente ligação. Com um olhar mais cuidadoso, entretanto, pode-se deduzir que a pretensão do narrador é demonstrar os elementos essenciais para a reconstituição do mundo que dava sentido ao ofício de buscar escravos fugidos. Para isso, ele faz um levantamento do instrumental utilizado por esse tipo de atividade.

É importante perceber que Machado constrói esse trecho dissertativo do texto, em parte, por um motivo que parece ir além dos aspectos materiais da obra. $\mathrm{O}$ autor confere, nesse primeiro trecho do texto, sinais sobre a posição do narrador que guiará a atenção dos leitores na história que se seguirá (FRANÇA NETO, 2008). Sidney Chalhoub já chamou a atenção para o fato de que os narradores são peças centrais na compreensão da temática racial e de gênero na obra machadiana (CHALHOUB, 2003). Dessa forma, faz-se importante construir a moldura da posição do narrador para que se possa apreender alguns dos seus sentidos fundamentais.

O texto começa com um lance de oposições. Esse jogo contrapõe os objetos da escravidão aos escravizados em uma relação que busca justificar as construções sociais 
daqueles pelas necessidades naturais desses. Assim, a sociedade senhorial construiu a máscara de folha-de-flandres para corrigir o vício da embriaguez dos escravos - articulada no texto como característica natural dos escravizados. Sem a vontade de beber perdiam também a de furtar, e "ficavam dous pecados extintos, e a sobriedade e a honestidade certas". Diz o narrador que "Era grotesca tal máscara, mas a ordem social e humana nem sempre se alcança sem o grotesco, e alguma vez o cruel'. O mal do aparato da escravidão se justificava pelo escravo.

Já nesse primeiro parágrafo existem dois elementos centrais do discurso senhorial brasileiro do século XIX. O mais evidente é o paternalismo escravista, tese frequente e muito bem recebida nos salões imperiais brasileiros, pela qual a escravidão favoreceria o africano escravizado. O contorcionismo intelectual da elite brasileira permitia defender que se não fosse a escravidão, os africanos estariam entregues à miséria, ao paganismo e à ausência de civilização na sua liberdade natal (BENEVIDES; FAGUNDES, 2018). Assim, o grande aparato da servidão servia justamente ao escravizado. Dessa forma, toleravam-se as consequências ruins e grotescas da escravidão - na simbologia do narrador, a máscara - por um bem maior social que traria ganhos a todos, brancosescravizadores e pretos-escravizados.

O segundo elemento que permite identificar o narrador como símbolo do discurso senhorial é a atribuição de características - em geral, ruins - próprias aos africanos e afrodescendentes. Assim, seriam vícios específicos, naturais aos escravos, o alcoolismo e o roubo. Logo em seguida, o narrador ressalta que nem todos gostavam da escravidão e de ganhar pancada - revelando a premissa de que, em geral, escravizados se submetiam de bom gosto à violência escravista. Estava armado o ambiente do racismo científico, e das hierarquias naturais das raças: os negros eram viciados, gostavam da escravidão, passivos, submissos, sem capacidade de ação.

Essa ideia de natureza está presente em todo o texto. O narrador usa o advérbio naturalmente seis vezes no conto. A primeira para dizer que a coleira de ferro era pesada, em um uso próprio - o ferro é pesado. A última para qualificar o amor de Cândido pelo filho, em uso também bastante comum. Todos os outros usos são interessantes. $\mathrm{O}$ narrador invoca o termo para colar características aos personagens em três ocasiões: Clara queria naturalmente casar; tia Mônica era naturalmente alegre e ajudava naturalmente a sobrinha nas tarefas de casa. Depois, o utiliza para dizer que naturalmente ninguém ouviu os pedidos de ajuda de Arminda. Ou seja, determinadas características das personagens seriam tão naturais quanto o peso do ferro e o amor de um pai pelo seu filho. Não era menos natural que Arminda fosse restituída ao seu senhor. As suas súplicas não poderiam ser recebidas como algo diferente do habitual - a sua escravidão, e a restituição da propriedade sobre seu corpo, também se dava pela natureza. 
O narrador mantém essa abordagem naturalista na condução de todo o texto, tratando as personagens de forma heterônoma. Cândido e Clara são retratados como bobos, rindo sem motivo, como se não se dessem conta de sua miséria. Não são responsáveis, não se importam com o futuro. Tia Mônica é egoísta, um pouco sádica, e age de forma instrumental, embora tenha consentido que a sobrinha se casasse com Cândido porque "era amiga de patuscadas, e o casamento seria uma festa, como foi". Como uma pessoa tão duramente consequente como ela - conforme demonstrado pela seca narração do conto - consentiria com um casamento por uma única festa? Em outro momento, em um sério debate sobre o futuro do filho do casal, novamente a tia de Clara ri porque previa "uma patuscada no batizado". Há um preconceito classista - talvez racista, como se discutirá - na hierarquia estabelecida entre narrador e personagens (RICCO, 2016).

Machado presenteia o seu leitor com um narrador muito bem localizado socialmente, e dotado de ideologia e de posição de classe bem demarcadas (CASTAÑEDA, 2012). Por isso, o narrador trata da escravidão como uma instituição antiga, quase esquecida no tempo. É o dever de esquecimento perpetrado pela direção senhorial nacional. As questões centrais do pensamento da classe dirigente brasileira (MANGUEIRA, 2009) - a sua superioridade racial, o determinismo e o naturalismo - estão presentes na tessitura da história contada.

Do mesmo modo, assim como a classe dirigente nacional, o narrador é incoerente. Apontando as suas visões gerais sobre africanos e afrodescendentes, ele não deixa de se contradizer. O ferro que seria para "educar" o escravizado, reaparece na sua narração como instrumento para facilitar a captura de escravo fugido; o vício da embriaguez era, antes, algo com o que "matar a sede"; a bondade do senhor transformase no sentimento de propriedade porque "dinheiro também dói". Por fim, os escravos supostamente passivos e enamorados do ambiente senhorial fugiam, lutavam, e buscavam cada brecha de liberdade possível, quando "o escravo de contrabando, apenas comprado no Valongo, deitava a correr, sem conhecer as ruas da cidade" ou outros, ainda ladinos, "pediam ao senhor que lhes marcasse aluguel, e iam ganhá-lo fora, quitandando". São ironias escondidas por Machado no texto, que acabam por descredenciar o narrador (NOVAIS, 2013).

Em parte, a posição classista do narrador explica a crueldade e a violência controlada do texto (NEVES, 2006). Além disso, sendo a sociedade dirigente brasileira também patriarcal, é possível ler a história a partir do conflito de gênero: há muito dessa moldura na disputa final entre Cândido e Arminda. Não deve ser por outro motivo que Cândido e Clara comemoram que o filho nascesse homem: o mundo de restrições para os pobres livres no Brasil era ainda maior para as mulheres (LEWIS, 2018). 
4. Cândido, Clara e Arminda: a sociedade escravocrata no conto de Machado

O narrador dá especial atenção, na parte inicial do conto, à máscara de folha-de-flandres. Após descrever seu uso, dar detalhes sobre as suas utilidades e o seu comércio, o narrador a retira do texto: "mas não cuidemos de máscaras". Conhecendo o narrador do conto - posicionado a partir dos preconceitos da classe senhorial brasileira - e sabendo-se da tradição de narradores não confiáveis presentes na obra de Machado (PEREIRA, 2009), cabe ao leitor justamente desconfiar, pensar sobre a centralidade das máscaras para a compreensão da história. De pronto, é impossível não estar atento à polissemia da palavra (FIALHO, 2016). Na definição de um importante dicionário do século XIX, máscara significava "peça feita de papelão ... para encobrir o rosto, com a feição deste. O sujeito que se mascara. Fig. Exterior, aparência"; o verbete mascarar aparecia como sinônimo de dissimular (PINTO, 1832, p. 543).

Há duas boas interpretações desse simbolismo. A primeira é a de que o texto vem para revelar as coisas como são, desmascará-las. É seguramente uma boa leitura considerando o fato de que o texto é direto, quase intragável, profundamente revelador das relações sociais brasileiras. A outra é a de que o texto trata de máscaras, de formas de se disfarçar, de projeções sociais que diferenciam as pessoas como são e como desejam parecer. Essa compreensão, também bastante razoável, projeta a discussão do texto diretamente para o debate sobre a raça de Cândido.

Pai contra Mãe foi entendido por muitos intérpretes como um texto sobre o conflito racial, a mulher negra escravizada e o branco pobre livre (CASTAÑEDA, 2012). Sendo esse trecho do trabalho destinado a situar a posição de Cândido e Clara na sociedade brasileira de então, e considerando que a raça e a cor são duas das principais contingências sociais de uma pessoa na sociedade escravocrata, faz-se fundamental investigar um pouco mais esse aspecto. Não é possível se chegar a uma conclusão acerca desse debate, mas existem bons indícios no texto indicando que, ao menos Cândido, e talvez Clara, eram pretos.

A porta de entrada para essa discussão é o nome dos personagens. Cândido é adjetivo daquilo que é "muito branco, alvo como a neve" (PINTO, 1832, p. 183). O sobrenome é Neves, duplicando sua afirmação como branco. A esposa é Clara. A primeira impressão é a de que os nomes seriam uma indicação de que ambos são brancos. Por outro lado, na sociedade escravocrata do século XIX é muito importante não ser preto conforme se avaliará na segunda parte desse trabalho. Além disso, como visto, o narrador deu centralidade à figura das máscaras para a composição da história. Assim, habilita-se a perspectiva de que os nomes poderiam ser sinais das tentativas de esconder a negritude.

Existem interessantes sinais nesse sentido. Alguns explícitos: em um trecho, o narrador, dizendo que o casal se divertia e ria muito, aponta que "os mesmos nomes eram objeto de trocados, Clara, Neves, Cândido; não davam que comer, mas davam que rir". 
Também falando das reflexões de Cândido sobre mudar de ofício, diz que o personagem considerava essa possibilidade "por simples gosto de trocar de oficio; seria um modo de mudar de pele ou de pessoa". O senhorio que cobrava aluguel da família trabalhava muito. Ao vê-lo "ninguém diria que era proprietário". Por fim, Arminda, caçada por Cândido, "voltou-se sem cuidar malícia. Foi só quando ele, tendo tirado o pedaço de corda da algibeira, pegou dos braços da escrava, que ela compreendeu e quis fugir".

Os nomes eram engraçados para eles, pois provavelmente algo inusitado se dava quando os comparavam consigo. Cândido cogitava trocar de pele, e relacionava tal desejo com o seu ofício. Seria o proprietário da casa, um preto? Não parecia proprietário. Seriam eles pretos, vivendo em uma vizinhança de pretos? Arminda não desconfiou que Cândido a caçasse. Mesmo depois de ouvir seu nome, não correu. Já havia visto Cândido, pois o narrador diz que ela apenas se assustou quando viu-lhe tirar um pedaço de corda. Estando fugida, por que não se assustou com Cândido? O fato de ele ser preto pode ter feito improvável para ela que ele estivesse a serviço do seu senhor? Seria a raça de Cândido uma vantagem no seu ofício de caçar escravizados?

Existem também indícios mais indiretos. Comparando o relacionamento de ambos e o primeiro ofício de Cândido - tipógrafo - o narrador diz que o livro, como metáfora da história de ambos, sairia "mal composto e pior brochado". Deve-se ainda lembrar das oposições das amigas de Clara à união. Em primeiro lugar, diziam que Cândido não seria um bom par pois dado a festas. Contestadas pela namorada de que seria bom não casar com um defunto, diziam: “-Não, defunto não; mas é que... Não diziam o que era". Há alguma crítica indizível das amigas, que fica apenas revelada nas entrelinhas do narrador. Poderia se tratar de um preconceito racial, o que explicaria o incômodo que tenciona a narrativa, mas que não se revela. A própria Clara, após não ser considerada para casar por vários namorados, quando viu Cândido, "sentiu que era este o possível marido, o marido verdadeiro e único". Por que os antigos namorados "apenas queriam matar o tempo; não tinham outro empenho", mas com Cândido o casamento poderia se realizar? Seria ela preta, tendo namorado um branco? Mulata, talvez? Somente com um negro, o casamento seria, de fato, possível?

Além disso, a oposição de tia Mônica à possibilidade de um filho também chama a atenção. As ideologias raciais de então pregavam a necessidade do branqueamento das classes. A mestiçagem era uma necessidade social de primeira ordem. Poderia ser esse o "pior brochado" do livro: o casamento de dois negros, recusando a oportunidade geracional de constituir uma geração mais clara? Ou o casamento de uma branca com um negro, o que seria um problema ainda maior?

Por fim, os debates sobre a raça de Cândido precisam ser lidos também à luz da sua opção por ser capitão do mato, caçador de escravos fugidos. Em primeiro lugar, a atividade detinha um certo prestígio social. $\mathrm{O}$ texto diz que embora não fosse nobre, o 
ofício contava com a nobreza implícita das ações reivindicadoras. O narrador se apressa em defender Cândido, dizendo que ninguém se metia em tal ofício senão pela pobreza, a necessidade e a inaptidão para outros trabalhos. Etimologicamente, Cândido é sinônimo de calmo, sereno. O simbolismo de ser chamado no diminutivo em família - Candinho - possivelmente indica um temperamento cordial, amistoso nas suas relações pessoais (MANGUEIRA, 2009, p. 2). Isso fica claro na falta de contestação às violências da tia, que o repreende constantemente.

A sua profissão o transforma (LEWIS, 2018, p. 5). Caçando escravos, sente um novo encantamento, mostrava-se orgulhoso. A atividade, prevista na legislação colonial desde o século XVII, fora regulamentada para destruir quilombos e desorganizar sistemas de fugas. Uma família de pretos com quatro membros poderia ser entendida como quilombola, e estar à mercê da caça de alguém que buscasse uma recompensa (ALENCASTRO, 2000, p. 345). Assim, havia um prestígio de garantidor da ordem pública nessa ação. Sendo preto, ser caçador de escravos seria uma forma se diferenciar (MANGUEIRA, 2009, p. 8). A literatura mostra casos de negros caçadores de escravizados: em alguns casos, acabaram por ser confundidos, inclusive, sendo presos como escravizados (ROCHA, 2016, p. 6).

Existem indícios de desconforto de Cândido em ser visto como escravo. Na ordem ideológica daquela sociedade - conforme se verá na próxima parte - há uma divisão muito clara das atividades destinadas aos escravos - trabalho manual, tarefas ordenadas a servir outras pessoas - e aos homens livres (FIALHO, 2016, p. 6). Sendo caçador, ele não precisava estar subordinado a ninguém, não precisava "estar longas horas sentado". O narrador conta que, no comércio, o incomodava "servir a todos". Provavelmente, está fazendo referência ao fato de ter que servir aos escravos também. Ao entrar na farmácia, já na última parte do conto, ele parece "falar como dono da escrava". Tudo isso deve ser considerado frente ao fato de que as profissões possíveis para Cândido - assim como para Clara no seu ofício de costureira - são subalternas, os aproximando da escravidão (LEWIS, 2018, p. 6). Preto ou branco, Cândido está inserido nas ideias de seu tempo: precisava se afastar do mundo da submissão escravocrata para se diferenciar. As máscaras do narrador ganham importância.

Os lances finais do conto são tenebrosos. O conflito do pai contra a mãe funciona pela perspectiva do narrador como apreensão do determinismo do século XIX, em que a continuidade da espécie - filho de Cândido - se habilita pela capacidade de vencer, superando os não adaptados - filho de Arminda. As ruas são sinais importantes: buscando a sua salvação, Cândido passa pela Rua do Parto e da Ajuda. Depois, ao agarrar Arminda, passa pela Rua dos Ourives e da Alfândega, possíveis referências à recompensa que Cândido receberia e à importação ilegal de escravizados que simbolizaria a violenta prisão de Arminda (FIALHO, 2016, p. 13). 
No fim, duas ideias podem estar escondidas no texto. A primeira se refere às formas de ação de Arminda. Em primeiro lugar, ela se oferece para trabalhar para Cândido. Buscava assim uma nova forma de liberdade, em um regime negociado, que lhe daria autonomia na escolha do senhor (MORAES, 2009, p. 8). Por fim, o conto termina com o aborto de Arminda, possivelmente induzido (PUGLIESI, 2018). Salvando seu filho da escravidão, Arminda teria libertado a sua procedência, punindo o senhor, que se desespera ao ver a morte do "fruto" de Arminda. O termo usado pelo narrador - em vez de filho - pode ser uma referência à propriedade escravizada pelo ventre (partus sequitur ventrem). Há uma sugestão de que Arminda pode ter praticado o aborto. Ao ser levada à casa do senhor, ela se esforça para "gastar mais tempo em lá chegar", possivelmente para ter tempo de ingerir uma droga abortiva. Antes, a única referência encontrada por Cândido sobre a escravizada fora na farmácia, onde o vendedor "se lembrava de ter vendido uma onça de qualquer droga, três dias antes, à pessoa que tinha os sinais indicados".

O filho sem nome de Cândido está inserido no mesmo ambiente de miséria de seus pais. Talvez seja negro, como se viu. Entretanto, ele não se iguala ao filho de Arminda, pois é livre (PEREIRA, 2016). Tia Mônica pode criticar a escravizada pelo aborto - "Disse, éverdade, algumas palavras duras contra a escrava, por causa do aborto" - embora tenha provavelmente sugerido o mesmo aborto para Cândido e Clara (ASSIS, [1906?], p. 6). Isso é possível pois Pai e Mãe estão inseridos em uma sociedade em que os códigos de conduta são diferentes, a partir do seu estado e de sua cor. O narrador usa a palavra espetáculo duas vezes no texto, para retratar a decisão de Cândido de entregar o filho para adoção e quando descreve o aborto de Arminda. Essas duas misérias são intercaladas pois são produtos de um mesmo sistema de restrições, e em alguma medida sobrevivem ao fim da escravidão, como importante parte de seu legado (MORAES, 2009, p. 3). Não são, entretanto, iguais.

\section{Homens e mulheres livres na ordem escravocrata}

A primeira parte do trabalho buscou detalhar os elementos centrais da narrativa, defendendo o argumento de que Cândido e Arminda estão articulados em um sistema de restrições sociais. Esse sistema tem formas de constituição e manutenção, e as instituições dele derivadas puderam, em grande medida, sobreviver à escravidão. Cândido, personagem fictício, deve ser avaliado pela sua agência moral. Entretanto, não é possível compreender as suas escolhas fora do regime de restrição social ao qual os homens e mulheres livres estão inseridos na ordem escravocrata. Nessa parte do trabalho se analisarão brevemente os eixos dessas balizas: em primeiro lugar, o direito, e depois, conjuntamente, a economia imperial e as ideologias formadoras daquela sociedade. 
6. Direito

No censo de 1872 , estimou-se que $60 \%$ dos cerca de 10 milhões de brasileiros eram pretos e pardos. Desses, $15 \%$ eram escravizados. A população preta e parda livre (cerca de 45\%) era muito superior à população escravizada, e mesmo à população branca. Moravam nas capitais provinciais apenas 10,41\% do país, com destaque para os municípios do Rio de Janeiro e Salvador, respectivamente com 274 e 129 mil pessoas (BRASIL, 1874). O Brasil era um país eminentemente rural.

Ao mesmo tempo que a escravidão se fortaleceu no século XIX brasileiro, parte importante de sua classe dirigente compreendeu as suas limitações. Aos poucos, sob as pressões e revoltas, os canhões ingleses, e alguma percepção das mudanças mundiais, o país passou a criar regimes jurídicos de transição. A ideia era permitir a continuidade de sistemas de controle quando do fim definitivo do sistema servil. Para tanto, as estratégias emancipacionistas buscaram construir saídas que mantivessem controle social e produtivo sobre os eixos centrais da riqueza nacional: trabalho e terra. Em um país de proporções continentais como o Brasil fazia-se importante constituir uma nova rede de constrições que compelisse a mão de obra livre ao pouco estimulante trabalho na lavoura nacional de exportação, evitando que tal força se espalhasse pelas disponíveis e ociosas terras nacionais.

Praticamente ao mesmo tempo da interrupção do tráfico negreiro, o parlamento brasileiro resolveu regular o acesso à terra, pela chamada Lei de Terras em 1850 (BRASIL, 1850). Buscando impedir o simples uso de espaços produtivos ou a concessão da possibilidade de sua exploração (sesmaria), a lei instituiu um regime liberal de uso do espaço, estipulando a compra como forma de aquisição de propriedade. Pensada como forma de financiamento e de proteção ao uso não desejado - agricultura de subsistência de trabalhadores desejados pela lavoura exportadora - a lei modernizou o sistema agrário nacional, o preparando também para o regime produtivo posterior ao fim do tráfico negreiro (SILVA, 2006). A terra, abundante em todo o período colonial, não poderia mais ser ocupada e cultivada por qualquer um.

Não foi diferente no campo do trabalho. Há um conjunto de legislações no século XIX que procura regular os contratos de locação e mão de obra no Brasil. Em tese, se trataria de situações de acordo de vontades, hipóteses nas quais os homens livres poderiam pactuar voluntariamente as suas condições de trabalho. Na prática, o trabalho de um homem livre no Brasil imperial é mais próximo da escravidão do que se poderia supor. Em primeiro lugar, poderia ser crime não trabalhar no Brasil. O art. 295 da lei executória do Código Criminal do Império dizia ser delito "Não tomar qualquer pessoa uma ocupação honesta, e útil, de que possa subsistir, depois de advertido pelo Juiz de Paz, não tendo renda suficiente". A pena era a de trabalhos forçados. Também o Código de 
Processo Criminal determinava que os juízes de paz poderiam "obrigar a assignar termo de bem viver aos vadios, mendigos, bêbados por hábito, prostitutas" (DANTAS; COSTA, 2016, p. 31). A lei é quase anedótica, um pouco esdrúxula. Pesquisas, entretanto, mostram a sua aplicação (SOUZA, 2015).

Três leis de locação de mão de obra livre foram aprovadas no século XIX. A primeira, de 1830, permitia que o tomador do serviço transferisse o contrato para terceiro, ainda que o instrumento registrasse expressamente o contrário. O prestador apenas poderia se negar a trabalhar restituindo os adiantamentos e pagando a metade do que ainda teria a ganhar caso o contrato fosse cumprido por inteiro. Em um contrato de 20 anos, caso alguém quisesse mudar de atividade no segundo ano, por exemplo, teria que indenizar, ao tomador, a metade do que receberia nos demais 18 anos de contratação. Os juízes estavam autorizados a constranger o trabalhador a cumprir a lei e o contrato (BRASIL, 1830).

Em 1837, uma nova lei foi aprovada pelo Parlamento. Com regras parecidas, autorizando a contratação de menores de idade, a Lei n. 108 foi voltada mais aos estrangeiros na organização dos sistemas de colonato. Não deixaram de estar presentes as ameaças penais pelo descumprimento da lei laboral, as regras que vinculavam o trabalhador ao contrato, e as imposições abusivas sobre a obrigação de indenizar os contratantes em diversos cenários (BRASIL, 1837). Em 1879, por fim, uma nova lei de locação foi promulgada. Mais estruturada, e já desenhada em um contexto de transição da escravidão, a norma constituía garantias ao cumprimento de contratos, cuidava das faltas e falhas dos contratantes, e impedia greves dos funcionários (BRASIL, 1879). A Lei Sinimbu atenuava as regras atinentes aos contratos assinados por estrangeiros, embora endurecesse o regime para os nacionais. Na prática, consolidava o novo sistema de mão de obra livre pós lei do Ventre Livre, constituindo cláusulas penais e renovações contratuais - sem a anuência do locador - que permitiam a continuidade de um sistema de baixa autonomia (LAMOUNIER, 1986).

Para os africanos e afrodescendentes, a situação era ainda mais violenta. Em primeiro lugar, vale lembrar que em novembro de 1831 a legislação nacional decretou livres todos os africanos traficados a partir daquela data. Estudos mostram que devem ter entrado mais de quinhentos mil africanos desde a proibição, o que faz com que uma parcela importante dos escravizados oficiais na segunda metade do século XIX fora, na verdade, ilegalmente escravizado (CONRAD, 1978; GRINBERG, 2007; RODRIGUES, 2000).

Machado de Assis menciona isso no começo do conto, falando dos escravos de contrabando. Ocorre que mesmo nos poucos casos em que houve liberdade para os traficados no período ilegal, os africanos livres foram submetidos a regime de trabalho forçado. Uma intrincada teia de favores legais e privilégios criou sistemas de distribuições 
desses africanos que, na prática, se transformaram em uma mão de obra quase cativa (MAMIGONIAN, 2017).

Quando a Lei do Ventre Livre libertou os filhos das escravizadas nascidos a partir de setembro de 1871, na verdade também os converteu em trabalhadores forçados. Vinculando-os aos senhores de suas mães, os riobrancos - como foram chamados os libertos pela Lei n. 2.040 - foram submetidos a um regime de trabalho compulsório de 21 anos, tempo supostamente necessário para que fossem educados à liberdade (BRASIL, 1871). Poderiam ser libertados antes, desde que indenizando o seu senhor. É verdade que a positivação da possibilidade de compra forçada foi um avanço da admissão de direitos já previstos pela tradição costumeira (SILVA JÚNIOR, 2015), entretanto o regime padrão de trabalho não se organizou senão pela mão de obra forçada.

Todo esse cenário é ainda preenchido pela realidade da escravização ilegal no Brasil. Ser preto no país significava estar em risco de ser reduzido à escravidão. Em Pai contra Mãe, Cândido se envolve em uma confusão tentando prender um homem livre. Sidney Chalhoub analisou essa situação, e demonstrou como autoridades, classe senhorial e sistemas legais funcionaram justamente para presumir a escravidão de pretos e pretas livres, restringindo seus direitos constitucionais, e acusando cidadãos plenos de direito de serem escravos fugidos. Presos, comercializados como escravizados ou postos a trabalhar forçadamente, os pretos estavam sempre submetidos a um risco adicional no Brasil. É o que Chalhoub chama de precariedade estrutural da liberdade (CHALHOUB, 2010).

A situação da chamada precariedade estrutural da liberdade também chama a atenção a uma questão central para a compreensão da realidade dos direitos no Brasil do século XIX: a prática jurídica tem uma relação tensa, conflituosa com a letra da lei. O Brasil era uma sociedade informal, cujas regras eram mal aplicadas, nem sempre conhecidas, e submetidas, na maior parte das vezes, a regimes privados de negociações, hierarquias e articulações. No limite, a história legal-formal das relações sociais diz muito pouco sobre a realidade efetiva da vida nacional. Entretanto, é razoável, a partir desses princípios legais, deduzir que se mesmo na formalidade legal se pode encontrar regimes profundamente restritivos, na prática, o cenário não deveria ser melhor: homens e mulheres livres na ordem escravocrata tinham profundas dificuldades de acesso à terra, e estavam submetidos a regimes precários de direitos nas suas relações de trabalho.

\section{Espaço econômico e ideologia}

A produção agrícola nacional, inserida perifericamente em um regime de expansão produtiva do atlântico norte, fez da escravidão um princípio unificador do sistema social brasileiro (FRANCO, 1997, p. 13). O regime de produção, constituído a partir de uma permanente necessidade de fonte externa de trabalho - a diáspora forçada 
dos africanos, por meio do tráfico negreiro -, fez dos homens livres e sem posses figuras estrangeiras ao sistema nacional, periféricas na construção da riqueza mercantil do país. Os homens livres se constituíram como dispensáveis, agregados precariamente ao sistema produtivo, em um não lugar que não os estabelecia na classe dos proprietários - embora, tivessem algum acesso produtivo -, sem também os reduzir à escravidão definitiva (FRANCO, 1997, p. 14).

Essa massa de homens livres, que se encaixa com dificuldade ao sistema produtivo nacional, desenvolve relações com as classes senhoriais que a subordina a um duplo controle: o patrimonialismo do favor e o império da violência (MORAES, 1998). Para cima, vivem submetidas a um regime discricionário de semi-vassalagem, que orienta suas ações às vontades senhoriais, seus caprichos e à admissão de uma espécie de proximidade consentida dos ganhos da riqueza nacional a partir da adoção de padrões de comportamentos e sociabilidade. Para baixo, a escassez e a redução dos sistemas de subsistência aos índices mínimos elevam a disputa pelas condições de vida a um nível de violência social que invade a vida privada, as relações de vizinhança, e a regulação geral da vida social (FRANCO, 1997, p. 56).

Produtores sem propriedade, essa classe dos homens livres se subordina ao sistema de favor, constituindo-se como dependentes da classe de proprietários. Sem possuir os dois ativos por excelência da sociedade escravocrata - terra e escravos - eles acessam os seus efeitos apenas indiretamente, a partir das concessões senhoriais. Schwarz chama a atenção para o fato de que esse ambiente do favor domina a classe dos não proprietários indistintamente, dos pretos pobres aos profissionais liberais, advogados e médicos. É esse jogo que subordina a vida da Corte, da Administração Pública, do Comércio e das Finanças ao norte conferido pela classe escravista nacional (SCHWARZ, 2012, p. 16).

O eixo central desse sistema é a vontade senhorial. O dependente - que tem como caricatura clássica a figura do agregado, bastante presente na prosa machadiana (SCHWARZ, 2012) - constrói sua vida a partir da inviolabilidade dessa vontade, e organiza sua ação como uma mera extensão desse poder senhorial. É uma forma de subsistência, de utilizar o paternalismo como elemento de agência (CHALHOUB, 2003, p. 58). Sem ser proprietário nem proletário, sua liberdade é mitigada pela necessidade econômica em virtude da ausência de utilidade no sistema produtivo (MANGUEIRA, 2009, p. 7).

Ideologicamente, não vigoraram no Brasil-nem mesmo retoricamente, como no caso europeu - os postulados burgueses da autonomia da pessoa, da universalidade da lei, da remuneração objetiva e da ética do trabalho (FIALHO, 2016, p. 5). A sobrevivência dessa classe intermediária depende exclusivamente da sua capacidade em se agregar aos interesses senhoriais, sem se permitir ser reduzida à violência total do escravismo. Essa marcha equilibrista é essencial para a manutenção da liberdade dependente. 
Esse processo de equilíbrio entre o extremismo total da classe senhorial antagonizada com a massa de escravizados, exige a adoção de determinados princípios ideológicos fortes. Como a análise da posicionalidade do narrador sugere, parte importante da manutenção do sistema escravista depende da construção de imagens sociais sobre a natureza dos escravizados e dos afrodescendentes em geral. Um regime tão brutal e violento como o do trabalho servil não pode sobreviver sem uma profunda construção linguística que comprometa toda - ou ao menos, parte significativa - a sociedade. Há o imperativo de um alinhamento que estabeleça acordos sobre a inferioridade e a imoralidade do escravizado, sem o qual há uma falência sistêmica: a empatia é essencialmente proibida porque desarticula mortalmente o sistema. A classe de homens livres precisa temer, odiar e desprezar os escravizados em um regime ideológico que obedece a dois pressupostos: (i) imitar a vontade senhorial; e (ii) dar garantias conceituais da sua diferenciação, evitando o risco da sua redução ao regime de escravidão.

Por outro lado, é importante lembrar que o Brasil é uma sociedade com relativa possibilidade de mobilidade social para os padrões de um regime escravocrata. Assim, é bastante importante considerar que uma parcela grande da população livre é justamente de pessoas saídas do cativeiro, ou de filhos de escravizados. A manumissão em suas várias formas, a existência dos escravos de ganho e dos escravizados que vivem por si, e o intenso ambiente da escravidão urbana permitem sistemas de mensuração de liberdade que exigem seus ritos e práticas sociais. Como se viu, o contingente de pretos e pardos livres no Brasil era quase três vezes maior que o de escravizados. Isso os coloca em profunda proximidade com a escravidão, conhecendo seus efeitos e seus riscos. Implica na ideia de que existem sistemas importantes de diferenciação social que, como dito acima, auxiliam na tarefa de não ser submetido, ou reinserido, à escravidão, e habilitam classes de dependentes a se constituírem como extensões das vontades senhoriais, fazendo-se úteis - ainda que de forma instável (IANNI, 1988).

\section{Conclusões}

Cândido é um homem livre na ordem escravocrata. Não tem espaço social, não tem função econômica. É um sujeito dependente da ordem senhorial, e apenas pode sobreviver se conseguir se acoplar à teia desses interesses, construindo-se como uma extensão das vontades do escravismo nacional. Vive dependente do regime do favor - tira seus sustentos das recompensas recebidas como forma de gratidão pelos seus serviços de caçar escravizados; vive em uma casa emprestada para a tia de sua esposa. Se relaciona pela violência, buscando na miséria dos escravizados, um quinhão pequeno que lhe permita viver. Não tem acesso à terra, monopolizada pela classe dirigente. Não pode ser 
um trabalhador formal, pois tal instituição o aproxima da escravidão. Foi educado em um ambiente linguístico de profunda antipatia ao escravizado.

É da natureza da sua posição social, o imperativo da diferenciação. Se branco, se inseriria nos preconceitos de raça, nas ideologias da superioridade da cor, aderindo às percepções de diminuição moral dos pretos e pretas. Se preto, além de todo o repertório ideológico ao qual não estaria necessariamente imune, precisa se diferenciar para poder acessar o sistema de intermediação social, ainda que de forma muito superficial. Antes de tudo, é importante evitar o maior mal possível a um afrodescendente no Brasil escravocrata: ser reduzido à escravidão.

O darwinismo do final do conto que articula o destino da continuidade da vida dos filhos de Cândido e de Arminda compreende a dependência dos seus sucessos. Metaforicamente, a descendência da escravizada está morta, condenada. A de Cândido pode sobreviver apenas precariamente. $\mathrm{Na}$ sociedade escravocrata, entretanto, não há espaço de isenção para a classe de despossuídos. Ambos os destinos são dependentes, intercalados. De fato, nem todos poderiam vingar.

Cambridge, 10 de maio de 2020.

\section{Referências}

ALENCASTRO, Luiz Felipe de. O trato dos viventes: formação do Brasil no Atlântico Sul. São Paulo: Companhia das Letras, 2000.

ASSIS, Machado de. Machado de Assis: obra completa. Rio de Janeiro: Nova Aguilar, 1994. v. 2.

ASSIS, Machado de. Memorial de Aires. [S. l.: s. n.], [1908?]. Disponível em: http://www. dominiopublico.gov.br/download/texto/bn000025.pdf. Acesso em: 1 maio 2020.

ASSIS, Machado de. Pai contra Mãe. [S. l.: s. n.], [1906?]. Disponível em: http://www. dominiopublico.gov.br/download/texto/bv000245.pdf. Acesso em: 1 maio 2020.

BENEVIDES, José Lucas Góes; FAGUNDES, Bruno Flávio Lontra. O paternalismo escravista em perspectiva na literatura: contrapontos entre o Demônio Familiar e Úrsula. Revista Interdisciplinar em Cultura e Sociedade (RICS), São Luís, v. 4, n. 2, p. 107-126, jul./dez. 2018.

BRASIL. Recenseamento do Brazil em 1872. Rio de Janeiro, [1874?]. Disponível em: https:// biblioteca.ibge.gov.br/biblioteca-catalogo.html?id=225477\&view=detalhes. Acesso em: 1 maio 2020.

BRASIL. Decreto n. 2827, de 15 de março de 1879. Rio de Janeiro, 29 mar. 1879. Disponível em: https://www2.camara.leg.br/legin/fed/decret/1824-1899/decreto-2827-15-marco-1879-547285publicacaooriginal-62001-pl.html. Acesso em: 1 maio 2020. 
BRASIL. Lei de 13 de setembro de 1830. Regula o contracto por escripto sobre prestação de serviços feitos por Brazileiro ou estrangeiro dentro ou fóra do Imperio. Rio de Janeiro, 20 set. 1830. Disponível em: https://www2.camara.leg.br/legin/fed/lei_sn/1824-1899/lei-37984-13-setembro1830-565648-publicacaooriginal-89398-pl.html. Acesso em: 1 maio 2020.

BRASIL. Lei $n .108$ de 11 de outubro de 1837. Dando varias providencias sobre os Contractos de locação de serviços dos Colonos. Rio de Janeiro, 14 out. 1837. Disponível em: http://legis.senado. leg.br/norma/541072/publicacao/15632760. Acesso em: 1 maio 2020.

BRASIL. Lei n. 2.40, de 28 de setembro de 1871. Declara de condição livre os filhos de mulher escrava que nascerem desde a data desta lei, libertos os escravos da Nação e outros, e providencia sobre a criação e tratamento daquelles filhos menores e sobre a libertação annaul de escravos... Rio de Janeiro, 28 jan. 1871. Disponível em: http://www.planalto.gov.br/ccivil_03/leis/lim/lim2040. htm. Acesso em: 1 maio 2020.

BRASIL. Lei $n$. 601, de 18 de setembro de 1850. Dispõe sobre as terras devolutas no Império, e acerca das que são possuídas por titulo de sesmaria sem preenchimento das condições legais. bem como por simples titulo de posse mansa e pacifica; e determina que, medidas e demarcadas as primeiras, sejam elas cedidas a titulo oneroso, assim para empresas particulares, como para o estabelecimento de colonias de nacionaes e de extrangeiros, autorizado o Governo a promover a colonisação extrangeira na forma que se declara. Rio de Janeiro, 20 set. 1850. Disponível em: http:// www.planalto.gov.br/ccivil_03/LEIS/L0601-1850.htm. Acesso em: 1 maio 2020.

CASTAÑEDA, Irene Zanette de. "Pai contra Mãe" de Machado de Assis: um olhar sócio-psicosemiótico. Revista Vozes dos Vales: Publicações Acadêmicas, [s. l.], n. 2, ano 1, out. 2012.

CHALHOUB, Sidney. 2010. Precariedade estrutural: o problema da liberdade no Brasil escravista (século XIX). História Social, Campinas, n. 19, p. 33-62, 2011.

CHALHOUB, Sidney. A força da escravidão: ilegalidade e costume no Brasil oitocentista. São Paulo: Companhia das Letras, 2012.

CHALHOUB, Sidney. Machado de Assis historiador. São Paulo: Companhia das Letras, 2003.

CONRAD, Robert Edgar. Os últimos anos da escravatura no Brasil. 2. ed. Rio de Janeiro: Civilização Brasileira, 1978.

DANTAS, Monica Duarte; COSTA, Vivian Chieregati. O "pomposo nome de liberdade do cidadão": tentativas de arregimentação e coerção da mão-de-obra livre no Império do Brasil. Estudos Avançados, São Paulo, v. 30, n. 87, p. 29-48, 2016.

DUARTE, Eduardo de Assis. Literatura afro-brasileira: um conceito em construção. In: AFOLABI, Niyi; BARBOSA, Márcio, RIBEIRO, Esmeralda (org.). A mente afro-brasileira = The AfroBrazilian mind. Trenton/Asmara: Africa World Press, 2007.

FIALHO, Elisângela Aparecida Lopes. Retratos da violência no Brasil do século XIX: "Pai contra Mãe”, de Machado de Assis. Jangada, Viçosa, n. 8, p. 57-72, jul-dez, 2016. 
FRAGELLI, Pedro Coelho. O Memorial de Aires e a abolição. Novos Estudos - CEBRAP, São Paulo, n. 79, p. 195-208, nov. 2007.

FRANÇA NETO, João Irineu de. A representação da escravidão nos Contos de Machado de Assis. 2008. Dissertação (Mestrado em Letras) - Universidade Federal da Paraíba, João Pessoa, 2008.

FRANCO, Maria Sylvia de Carvalho. Homens livres na ordem escravocrata. 4. ed. São Paulo: UNESP, 1997.

GRINBERG, Keila. Senhores sem escravos: a propósito das ações de escravidão no Brasil Imperial. Revista Almanack Braziliense, São Paulo, n. 6, p. 4-13, 2007.

IANNI, Octavio. As metamorfoses do escravo. 2. ed. São Paulo: HUCITEC, 1988.

LAMOUNIER, Maria Lúcia. O trabalho sob contrato: a lei de 1879. Revista Brasileira de História, São Paulo, v. 6, n. 12, p. 101-124, mar./ago. 1986.

LEWIS, Christopher John Tudor. To beat or abet in Machado de Assis > "Pai contra Mãe": the text in superposition. Machado de Assis em Linha, São Paulo, v. 11, n. 24, p. 94-115, May/Aug. 2018.

MAMIGONIAN, Beatriz Gallotti. Africanos livres: a abolição do tráfico de escravos no Brasil. São Paulo: Companhia das Letras, 2017.

MANGUEIRA, José Vilian. "Nem todas as crianças vingam": relação social em "Pai contra Mãe". Darandina Revisteletrônica, Juiz de Fora, v. 2, n. 1, maio 2009.

MORAES, Reginaldo C. Homens livres na ordem escravocrata. Educação \& Sociedade, Campinas, v. 19 , n. 62 , p. 184-188, abr. 1998.

MORAES, Renata Figueiredo. Pai contra Mãe: a permanência da escravidão nos contos de Machado de Assis. In: ESCRAVIDÃO E LIBERDADE NO BRASIL MERIDIONAL, 4., 2009, Curitiba. Anais [...]. Curitiba: [s. l.], 2009.

NEVES, Rita Ciotta. "Pai contra Mãe" de Machado de Assis: um grito contra a escravatura. Revista Babilónia, Lisboa, n. 4, p. 31-39, 2006.

NOVAIS, Mayara Michele Santos. O ideal de racionalidade presente no conto "Pai contra Mãe", de Machado de Assis. In: ENCONTRO NACIONAL DE PESQUISADORES DE PERIÓDICOS LITERÁRIOS, 4., 2010, Feira de Santana. Anais [...]. Feira de Santana: Uefs, 2013.

PARRON, Tâmis Peixoto. A política da escravidão no Império do Brasil. Rio de Janeiro: Civilização Brasileira, 2011.

PEREIRA, Cilene Margarete. Em busca do "narrador machadiano": a experiência dos primeiros contos. Darandina Revisteletrônica, Juiz de Fora, v. 2, n. 2, jun. 2009.

PEREIRA, Robson de Freitas. "Pai contra Mãe": quando o outro não é semelhante. Machado de Assis em Linha, São Paulo, v. 9, n. 17, p. 23-32, abr. 2016. 
PINTO, Luiz Maria da Silva. Diccionario da lingua brasileira. Ouro Preto: Typographia de Silva, 1832.

PUGLIESI, Lucas Bento. Estamos vivos aos olhos de Machado? - A ideologia através de pontos de vista sobre "Pai contra Mãe". RELACult, Foz do Iguaçu, v. 4, n. 2, maio/ago., 2018.

RIBEIRO, Júlio. Grammatica portugueza. São Paulo: Teixeira \& irmãos, 1883.

RICCO, Giulia. Framing violence: narrator and reader in "Pai contra Mãe". In: AIDOO Lamonte; SILVA, Daniel F. (ed.). Emerging dialogues on Machado de Assis. New York: Palgrave Macmillan, 2016.

ROCHA, Fernando Sousa de. "Father versus mother": slavery and its apparatuses. In: AIDOO Lamonte; SILVA, Daniel F. (ed.). Emerging dialogues on Machado de Assis. New York: Palgrave Macmillan, 2016.

RODRIGUES, Jaime. O infame comércio: propostas e experiências no final do tráfico de africanos para o Brasil, 1800-1850. Campinas: Unicamp, 2000.

SCHNEIDER, Alberto Luiz. Machado de Assis e Silvio Romero: escravismo, "raça" e cientificismo em tempos de campanha abolicionista (década de 1880). Almanack, Guarulhos, n. 18, p. 451-488, abr. 2018.

SCHWARZ, Roberto. Ao vencedor as batatas: forma literária e processo social nos inícios do romance brasileiro. 6. ed. São Paulo: Editora 34, 2012.

SILVA JÚNIOR, Waldomiro Lourenço da. Entre a escrita e a prática: direito e escravidão no Brasil e em Cuba, c.1760-1871. 2015. Tese (Doutorado em História Social) - Faculdade de Filosofia, Letras e Ciências Humanas, Universidade de São Paulo, São Paulo, 2015.

SILVA, Claudia Christina Machado e. Escravidão e grande lavoura: o debate parlamentar sobre a lei de terras (1842-1854). 2006. Dissertação (Mestrado) - Departamento de História, Setor de Ciências Humanas Letras e Artes, Universidade Federal do Paraná, Curitiba, 2006.

SIMÃO, José Fernando. Notas sobre as relações familiares no período das Ordenações Filipinas. Carta Forense, São Paulo, 27 dez. 2013. Coluna de Civil.

SOUZA, Thaís Pinhata de. Fragilidade resistente: mulheres e os termos de bem-viver no último quartel do século XIX. 2016. Dissertação (Mestrado em Direito) - Faculdade de Direito, Universidade de São Paulo, São Paulo, 2015. 
